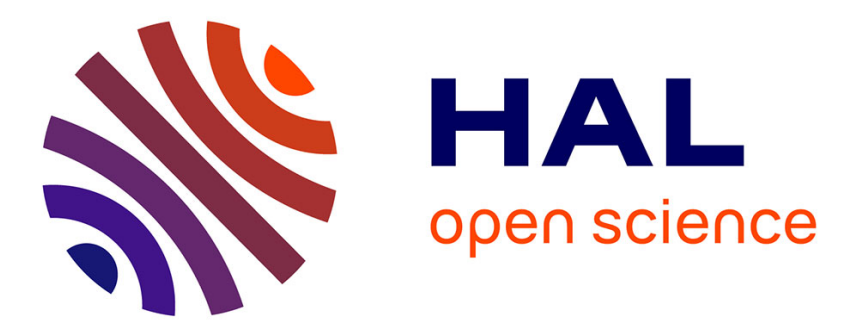

\title{
Energy requirement for fine grinding of torrefied wood
}

Vincent Repellin, Alexandre Govin, Mathieu Rolland, René Guyonnet

\section{To cite this version:}

Vincent Repellin, Alexandre Govin, Mathieu Rolland, René Guyonnet. Energy requirement for fine grinding of torrefied wood. Biomass and Bioenergy, 2010, 34 (7), pp.923-930. 10.1016/j.biombioe.2010.01.039 . hal-00508334

\section{HAL Id: hal-00508334 \\ https://hal.science/hal-00508334}

Submitted on 3 Aug 2010

HAL is a multi-disciplinary open access archive for the deposit and dissemination of scientific research documents, whether they are published or not. The documents may come from teaching and research institutions in France or abroad, or from public or private research centers.
L'archive ouverte pluridisciplinaire HAL, est destinée au dépôt et à la diffusion de documents scientifiques de niveau recherche, publiés ou non, émanant des établissements d'enseignement et de recherche français ou étrangers, des laboratoires publics ou privés. 


\title{
Energy requirement for fine grinding of torrefied wood
}

\author{
REPELLIN Vincent(1), GOVIN Alexandre(1)*, ROLLAND Mathieu(2), GUYONNET René(1)
}

(1) Ecole Nationale Supérieure des Mines de Saint Etienne, Centre SPIN - Département PMMC ; LPMG-UMR CNRS 5148, 158 Cours Fauriel - 42023 Saint-Étienne Cedex 2, France

(2) IFP-Lyon, Direction Expérimentation Procédés, Rond-Point de l'échangeur de Solaize, 69390 Solaize, France

\begin{abstract}
The purpose of this study is to investigate the influence of torrefaction on wood grinding energy. Wood chips were torrefied at different temperatures and durations. The energy required to obtain fine powder was measured. Particle size analyses were carried out on each powder sample. It is showed that torrefaction decreases both grinding energy and particle size distribution. A criterion to compare grindability of natural and torrefied wood is proposed. It takes into account both grinding energy and particle size distribution. It accounts the energy required for grinding particles to sizes inferior to $200 \mu \mathrm{m}$, for given grinding conditions. Torrefaction is characterised by the anhydrous weight loss (AWL) of wood. For AWL inferior to around 8\%, grinding energy decreases fast. Over 8\%, grinding energy decreases at a slow rate. Particle size distribution decreases linearly as the AWL increases. Both for spruce and beech, the grinding criterion is decreased of $93 \%$ when the AWL is around $28 \%$.
\end{abstract}

Keywords:

Torrefaction; Grinding; Wood; Energy; Particle size distribution

\section{Introduction}

Facing fossil fuel resources decrease and green house gases emission concerns, it becomes crucial to enhance the use of biomass as a source of energy. Wood and biomass contain a lot of available energy. For example, the low heating value (LHV) of dry wood ranges between 4300 and $5400 \mathrm{kWh} / \mathrm{t}$, depending on the species. Biomass can potentially supply $14 \%$ of the total world's energy requirement. For this aim, different ways are considered such as direct combustion, co-firing in power plants, production of biomass based motor fuel [1]. Different possibilities for making motor fuel from biomass can be developed such as agrochemical processes [2], biological processes and thermo-chemical processes [3]. Among thermochemical treatments of biomass, gasification followed by Fischer-Tropsch synthesis is of particular interest [4] and [5]. It allows producing diesel of high quality, using ligno-cellulosic material from the entire plant. Different studies are carried out at the moment to improve the yield of the Fischer-Tropsch [6] and [7].

Such thermo-chemical treatments require preliminarily a fine grinding of wood in order to increase reaction rates and gas yield. Some authors have shown that $200 \mu \mathrm{m}$ is the approximate size below which pyrolysis reactions are kinetically controlled [8] and [9]. Gasification reaction appears to behave similarly at the beginning so that we have kept the $200 \mu \mathrm{m}$ specification. Nevertheless, biomass or wood has viscous-elastic and plastic behaviour. A lot of energy is thus dissipated in the material before failure. Consequently, grinding wood or biomass is very energy consuming. General ideas concerning wood grinding

* Auteur à qui la correspondance devait être adressée : govin@emse.fr 
are that shearing, shredding and cutting are preferable to bending, compaction friction and tensile strength [10]. Himmel et al. showed that for similar particles size reduction, energy requirement is higher with a hammer mill than with a knife mill [11]. To obtain aspen wood powder with a d50 between $500 \mu \mathrm{m}$ and $250 \mu \mathrm{m}$, these authors found typical net grinding energies values around $120 \mathrm{kWh} / \mathrm{t}$. Straw required grinding energies less than $50 \mathrm{kWh} / \mathrm{t}$. Other studies showed that higher energy consumption is necessary with attrition mill or explosion depressurisation than with knife mills [12]. For coarser grinding (d50 around $840 \mu \mathrm{m}$ ), energy requirements were $453 \mathrm{kWh} / \mathrm{t}$ for explosive depressurisation and $783 \mathrm{kWh} / \mathrm{t}$ for attrition mill. Fine grinding with attrition mill (d50 close to $105 \mu \mathrm{m}$ ) required $1900 \mathrm{kWh} / \mathrm{t}$. Optimising grinding process with hammer mills, Esteban and Carrasco obtained $130 \mathrm{kWh} / \mathrm{t}$ for poplar and $170 \mathrm{kWh} / \mathrm{t}$ for pine, for a d50 approximately around $500 \mu \mathrm{m}$ [13]. By comparison typical coal grinding energy range between $7 \mathrm{kWh} / \mathrm{t}$ and $36 \mathrm{kWh} / \mathrm{t}$.

Other properties are also involved in the good progress of gasification or pyrolysis, in particular handling properties of wood powder, particles sizes and shapes, moisture content and energy density. Handling characteristics of wood powder is of primary importance for an easy injection in the thermo-chemical reactor. Natural ground wood particles have mainly needle shapes that confer a low flowability and a poor fluidisation behaviour to the power. Reina et al found that wood powder has a cohesive behaviour according to Geldart classification [14] and [15]. Type of mill used to grind wood influences particles shape and powder flowability. The tendency to bridge is lower for powders ground in knife mills than for powders ground in hammer mils, owing to particles size and shape [16]. This bad flowability of wood powder is a drawback for conversion processing. To improve this property, new types of mills are being developed. For example, vibration mills decrease grinding energy requirements, and lead to round shaped particles [17].

Torrefaction is intended to modify wood or biomass properties, and to make easier its preparation for thermo-chemical treatments. In a more accurate way, torrefaction is a heat treatment of ligno-cellulosic material carried out at temperatures less than $300{ }^{\circ} \mathrm{C}$ [18]. From the structural point of view, wood is composed of three main structure constituents: cellulose (35-40 weight \%), hemicelluloses (20-30 weight \%) and lignin (20-30 weight \%). It contains also 1-4 weight \% of extractives compounds [19]. During torrefaction, slow pyrolysis predominates: wood is thermally decomposed at a slow rate [20] and [21]. At temperatures below $300{ }^{\circ} \mathrm{C}$, the main products of wood decomposition are water, carbon dioxide, carbon monoxide, formic acid, acetic acid and furfural. Many studies have shown that these products correspond mainly to the hemicelluloses decomposition. Nevertheless, lignin and cellulose undergo also some depolymerisation and decomposition, in particular when the temperature goes over $25 \mathrm{O}^{\circ} \mathrm{C}$ [22] and [23].

In contrast to natural wood, torrefied wood has a brittle behaviour and a decreased strength. A lot of energy necessary for powdering wood may thus be saved [24]. Rapp et al. noticed the relationship between heat treatment severity and wood embrittlement [25]. From studies concerning massive wood for decking applications, it is well known that mechanical strength of the material is decreased during heat treatment. Wood strength can be severely decreased according to the atmosphere, temperature and duration of the heat treatment [26] and [27]. Moreover torrefaction has other advantages: it increases the carbon content of wood as well as its energy content [28] and [29]. Material moisture content and hygroscopicity are decreased [30]. According to certain studies, torrefaction enhances wood powder flowability and fluidisation behaviour. The advantages provided by torrefaction may also be useful for cofiring, or pellets manufacturing [31] and [32].

The purpose of this study is to investigate the influence of torrefaction on wood grinding energy. Wood chips were torrefied at different temperatures and durations. The energy required to obtain fine powder was measured. Particle size analyses were carried out on each powder sample. The influence of torrefaction temperature and duration on grinding energy and powder particle size was examined. A comparison criterion is proposed to compare the grindability of natural and torrefied wood. 


\section{Materials and methods}

\section{II.1. Experimental procedure}

Figure 1 shows the experimental procedure followed for this work. At first, wood chips were torrefied at different temperatures and durations. Then, a pre-grinding was carried out in a first mill. Afterwards, pre-ground material was sieved. For each batch, the same sieve fraction (2-4 mm) was collected and employed for fine grinding. During fine grinding, energy measurements were done. The particles sizes of the resulting fine powder were analysed by laser diffraction.

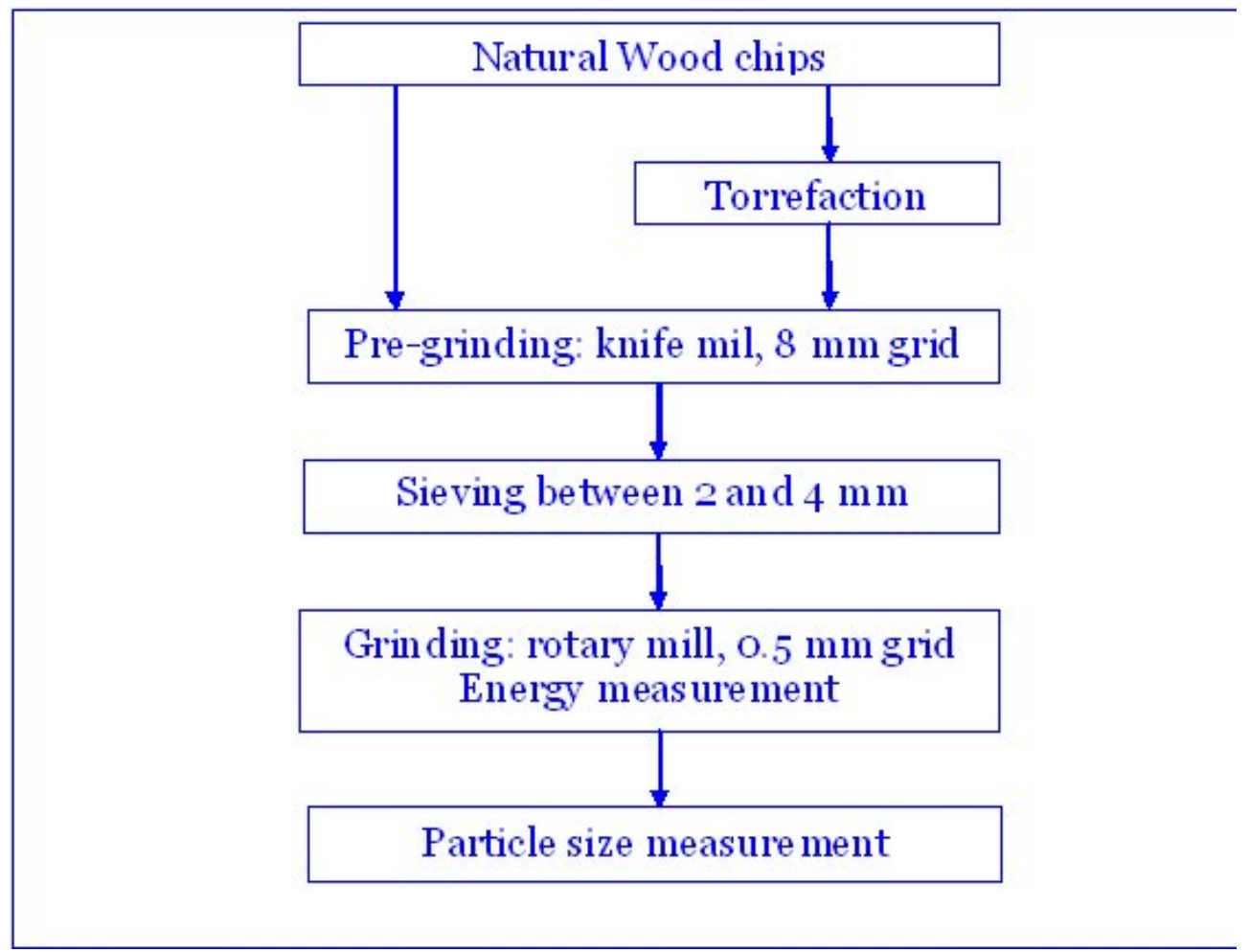

Figure 1: Experimental procedure.

\section{II.2. Torrefactions}

Torrefactions were carried out in a pilot kiln designed at the Ecole des Mines de SaintEtienne, as previously described by Repellin et al. [18]. [Table 1] and [Table 2] show the torrefaction parameters and the corresponding anhydrous weight losses (AWL). Wood chips were of two species: spruce and beech. Each run is labelled according to three codes. The first one is the wood chips specie ( $\mathrm{S}$ for spruce and B for beech), the second one is the torrefaction temperature and the third one is the duration. For example, a run labelled B-240-20, is a torrefaction of beech wood chips carried out at $240{ }^{\circ} \mathrm{C}$ during $20 \mathrm{~min}$.

Table 1: Torrefaction of spruce chips: nomenclature, parameters and anhydrous weight loss.

\begin{tabular}{|l|lll|}
\hline Name & $\begin{array}{l}\text { Torrefaction } \\
\text { temperature } \\
\left({ }^{\circ} \mathbf{C}\right)\end{array}$ & $\begin{array}{c}\text { Torrefaction } \\
\text { duration } \\
\text { (min) }\end{array}$ & $\begin{array}{l}\text { Anhydrous } \\
\text { weight loss } \\
\text { (\%) }\end{array}$ \\
\hline S-160-5 & 160 & 5 & 0 \\
S-200-5 & 200 & 5 & 0.7 \\
S-220-5 & 220 & 5 & 1.3 \\
S-240-5 & 240 & 5 & 5.2 \\
S-260-5 & 260 & 5 & 7.8 \\
S-280-5 & 280 & 5 & 17.2 \\
S-300-5 & 300 & 5 & 26.4 \\
\hline
\end{tabular}

In a first stage torrefaction temperature was investigated, for spruce and beech. For this first stage, torrefaction duration was kept equal to $5 \mathrm{~min}$. The second stage investigated torrefaction duration until $60 \mathrm{~min}$. This second stage was carried out only for beech wood, at torrefaction temperature of $220^{\circ} \mathrm{C}, 240{ }^{\circ} \mathrm{C}$ and $260{ }^{\circ} \mathrm{C}$. 
Biomass \& Bioenergy, 2010, 34(7), 923-930, doi:10.1016/j.biombioe.2010.01.039.

Table 2: Torrefaction of beech chips: nomenclature, parameters and anhydrous weight loss.

\begin{tabular}{|l|lll|}
\hline Name & \multicolumn{1}{|c|}{$\begin{array}{c}\text { Torrefaction } \\
\text { temperature }\left({ }^{\circ} \mathbf{C}\right)\end{array}$} & $\begin{array}{c}\text { Torrefaction } \\
\text { duration (min) }\end{array}$ & $\begin{array}{c}\text { Anhydrous } \\
\text { weight loss } \\
\text { (\%) }\end{array}$ \\
\hline B-180-5 & 180 & 5 & 0.0 \\
B-200-5 & 200 & 5 & 0.0 \\
B-220-5 & 220 & 5 & 3.7 \\
B-240-5 & 240 & 5 & 8.2 \\
B-260-5 & 260 & 5 & 15.1 \\
B-280-5 & 280 & 5 & 28.1 \\
\hline B-220-20 & 220 & 20 & 5.2 \\
B-240-20 & 240 & 20 & 11.5 \\
B-260-20 & 260 & 20 & 21.2 \\
\hline B-220-40 & 220 & 40 & 7.7 \\
B-240-40 & 240 & 40 & 16.0 \\
B-260-40 & 260 & 40 & 23.4 \\
\hline B-220-60 & 220 & 60 & 8.0 \\
B-240-60 & 240 & 60 & 16.0 \\
B-260-60 & 260 & 60 & 25.6 \\
\hline
\end{tabular}

\section{II.3. Pre-grinding}

Natural chips and torrefied chips of each batch were pre-ground in a knife mill Retsch SM1 equipped with an $8 \mathrm{~mm}$ grid. The material was collected and automatically sieved between $2 \mathrm{~mm}$ and $4 \mathrm{~mm}$. The different sieve fractions were weighted in order to measure the influence of torrefaction on the particles size. This pre-grinding had two purposes. Firstly, it reduced the particle size so that they could be introduced in the fine grinding mill. Secondly, this procedure allowed filling the fine grinding mill always with particles of the same size (2$4 \mathrm{~mm}$ sieve fraction). This procedure leads to comparable energy and particle size measurements concerning fine grinding.

\section{II.4. Fine grinding and grinding energy measurement}

For natural wood and torrefied wood, four samples of $30 \mathrm{~g}$ of well defined size particles were employed for fine grinding. They were finely ground in an ultra centrifugal mill (Retsch ZM 1). This type of mill can be equipped with grid of holes of different diameters. Simmons et al. and Wei et al. [8] and [9], showed that particles for thermo-chemical treatments should be inferior to $200 \mu \mathrm{m}$ to avoid thermal transfer.

Several grids were tested. We selected the grid that produced most particles less than $200 \mu \mathrm{m}$ and the least grinding energy. The $500 \mu \mathrm{m}$ grid was chosen for this aim. It allowed relevant observation of the influence of torrefaction on the volume fraction of particles inferior to $200 \mu \mathrm{m}$.

The grinding mill nominal power was $400 \mathrm{~W}$. The mill was fed with a vibrating feeder type Retsch D100. The feeding rate was adjusted according to the material to ensure a power of the mill motor close to its nominal value. A numerical watt meter ISW 8350 from IeS (Instruments and Systems) was employed to record the electrical power during grinding in the ZM1 mill. The power of this mill under no load conditions was measured at $280 \mathrm{~W}$. However it was not subtracted to the power curve recorded during sample grinding. Thus, the total grinding energy $(E)$ was evaluated by integration of the power curve over grinding duration. It counts both the energy required to the mill in no load conditions and the energy necessary to grind wood particles.

\section{II.5. Particle size determination}

Each powder sample was analysed by laser particle size analysis (Malvern Mastersizer 2000 instrument equipped with a sirocco $2000(\mathrm{~A})$ cell). Disperser pressure was set to $3.5 \mathrm{bar}$, and feed rate was $60 \%$. We define $\mathrm{X}_{<200 \mu \mathrm{m}}$ as the volumetric percentage of particles of diameter inferior to $200 \mu \mathrm{m}$. 


\section{Results}

\section{III.1. Pre-grinding}

Figure 2 shows the sieve fraction inferior to $2 \mathrm{~mm}$ in weight percent (WFI2), resulting from beech and spruce pre-grinding. As torrefaction temperature increases, the WFI2 increases, both for beech and spruce. The necessity to sieve and to employ the same sieve fraction in the ZM1 mill was thus confirmed. Variations of particles sizes happen in three steps. During the first step, WFI2 increases from natural spruce (18\%) to torrefied spruce (S-160-5, 23\%). Concerning beech, it increases in the same way from the natural state (18\%) to B-180-5 (23\%). The second step shows a constant value of WFI2. For Spruce, it is unchanged from S160-5 to S-240-5. Concerning beech, the temperature range of this second step is small: from B-180-5 to B-200-5. The third step begins at temperatures from which WFI2 increases significantly. For spruce, it begins to increase for S-260-5 (26\%). It represents respectively $32 \%$ for S-280-5 and 35\% for S-300-5. Concerning beech, it is increased progressively from B200-5 (24\%) to B-280-5 (43\%), with a rather large step present between B-200-5 and B-2205 .

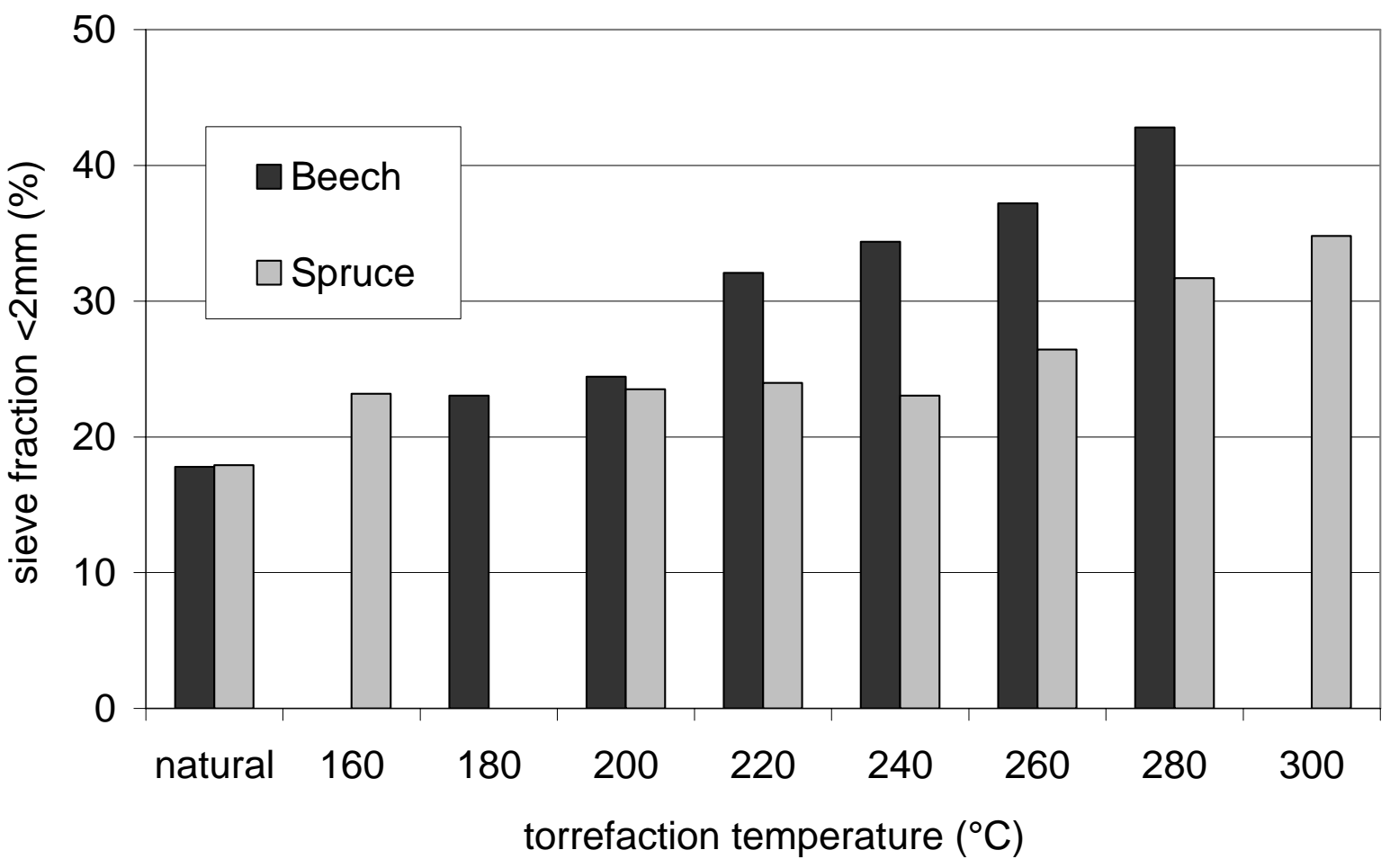

Figure 2: Pre-grinding of beech and spruce: weight percent of sieve fraction of particles inferior to $2 \mathrm{~mm}$ as a function of torrefaction temperature

\section{III.2. Fine grinding energy}

Figure 3 shows the energy required for grinding beech and spruce with a $500 \mu \mathrm{m}$ grid. Fine grinding of natural wood requires a lot of energy: about one-sixth of its LHV. Natural spruce requires less grinding energy than natural beech (respectively $750 \mathrm{kWh} / \mathrm{t}$ and $850 \mathrm{kWh} / \mathrm{t}$ ). Grinding energy is amazingly decreased by torrefaction. For example, it is possible to spare $90 \%$ of beech grinding energy at $280^{\circ} \mathrm{C}$. At high temperature, grinding energies of beech and spruce decrease to values inferior to $100 \mathrm{kWh} / \mathrm{t}$. Grinding energy of spruce is decreased of $40 \%$ between natural state and $\mathrm{S}-160-5$, whereas beech grinding energy is decreased only of $14 \%$ between natural state and B-180-5. When temperature increases over $200{ }^{\circ} \mathrm{C}$ for spruce and for beech; grinding energy decreases progressively. From $200{ }^{\circ} \mathrm{C}$ to $300{ }^{\circ} \mathrm{C}$, this decrease is at a low and rather constant rate for spruce. For beech, the rate of energy decrease is high at temperatures from $180^{\circ} \mathrm{C}$ to $240{ }^{\circ} \mathrm{C}$, and rather low from $240{ }^{\circ} \mathrm{C}$ to $280^{\circ} \mathrm{C}$. 


\section{III.3. Fine powder particle size distribution}

[Figure 4] and [Figure 5] show cumulative particle size distribution of spruce and beech fine powders. [Table 3] and [Table 4] summarise the main particle size properties: mode, average particle size and $\mathrm{d}_{50}$. For spruce wood, there is a decrease of particle sizes between natural state and S-160-5 (Table 3). Then, there is only a small decrease of particle sizes from S-160-5 to S-240-5. Above $240{ }^{\circ} \mathrm{C}$, any temperature increase lead to a high decrease of the mode, average size particle, and d5o, as it is visible both on Figure 4 and Table 3. Concerning beech, the particle size distribution is unchanged or slightly increased at $180^{\circ} \mathrm{C}$ and $200{ }^{\circ} \mathrm{C}$ (Table 4). It is followed by a significant decrease visible for B-220-5. This decrease goes on as the torrefaction temperature increases (Figure 5). The two species behave differently. The effect of torrefaction on powder fineness is stronger for spruce than for beech at temperatures superior to $240{ }^{\circ} \mathrm{C}$.

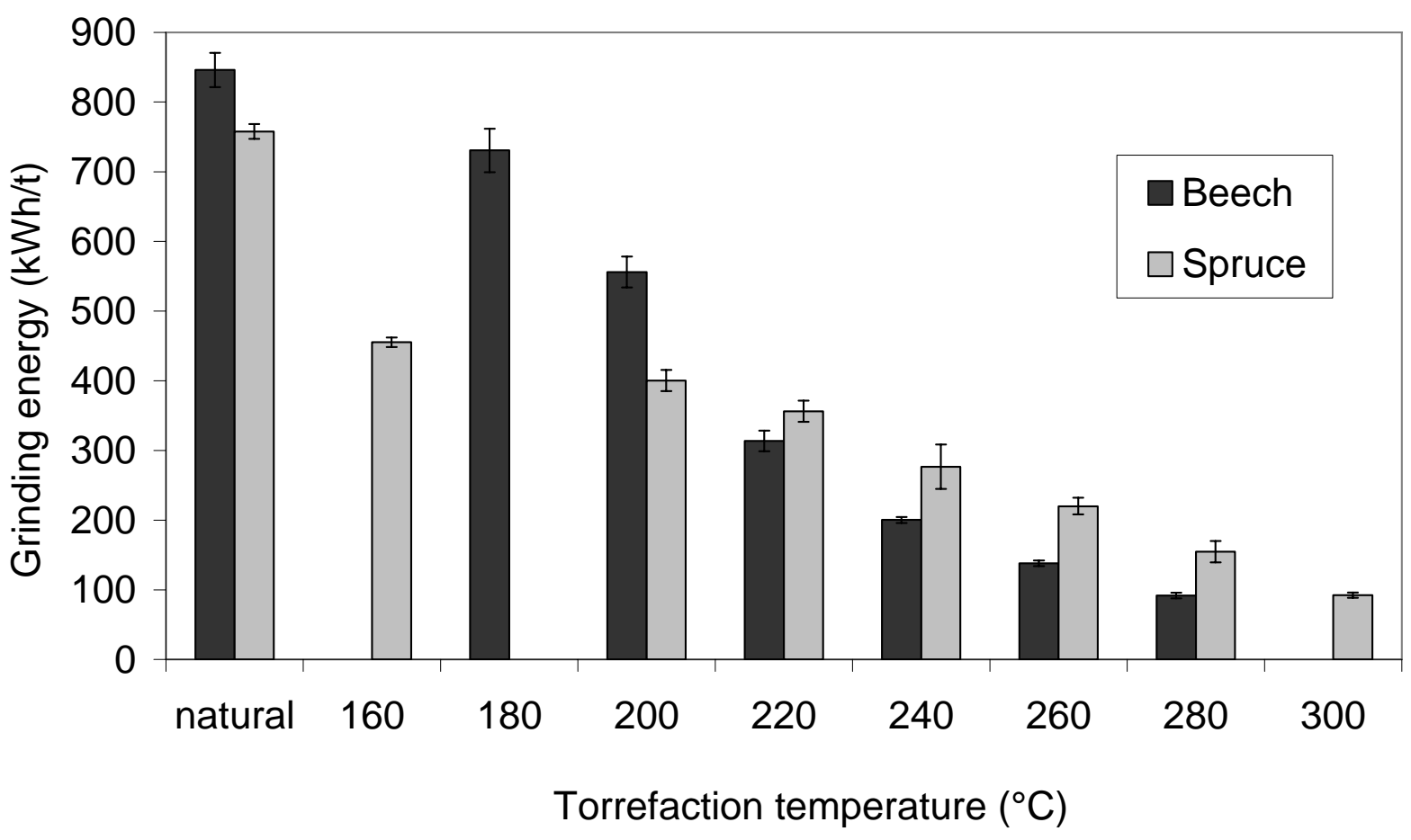

Figure 3: Grinding energy of beech and spruce as a function of torrefaction temperature, obtained with a Retsch ZM1 ultra centrifugal mill, equipped with a 500 um grid.

\section{III.4. Influence of torrefaction duration}

On Figure 6, grinding energy of beech torrefied at $220^{\circ} \mathrm{C}, 240{ }^{\circ} \mathrm{C}$ and $260{ }^{\circ} \mathrm{C}$ for $5 \mathrm{~min}$ to $60 \mathrm{~min}$ is presented. For each temperature, the AWL also increases during the first $20 \mathrm{~min}$ and is almost constant afterwards (Table 2). Correlatively, grinding energy decreases during 20 min of torrefaction. Then, it is almost constant until $60 \mathrm{~min}$. Particle sizes decrease significantly for treatments of 5 and 20 min (Figure 7 and Table 4). When duration increases to 40 and 60 min particle sizes do not vary.

Table 3: Properties of particle size distribution of spruce wood powder, obtained with a Retsch ZM1 ultra centrifugal mill equipped with a 500 um grid (Average of 4 samples, standard deviation in brackets.).

\begin{tabular}{|l|lll|}
\hline Name & Mode ( $\mathbf{m})$ & $\mathbf{D}_{[\mathbf{4}, 3]}(\mathbf{\mu m})$ & $\mathbf{D}_{\mathbf{5 0}}(\boldsymbol{\mu m})$ \\
\hline S-N & $280(3)$ & $237(10)$ & $197(5)$ \\
S-160-5 & $264(6)$ & $219(8)$ & $178(3)$ \\
S-200-5 & $251(5)$ & $214(10)$ & $173(7)$ \\
S-220-5 & $247(7)$ & $193(2)$ & $157(4)$ \\
S-240-5 & $228(14)$ & $197(14)$ & $152(16)$ \\
S-260-5 & $194(7)$ & $162(7)$ & $118(7)$ \\
S-280-5 & $169(10)$ & $137(8)$ & $93(7)$ \\
S-300-5 & $50(6)$ & $97(6)$ & $59(5)$ \\
\hline
\end{tabular}




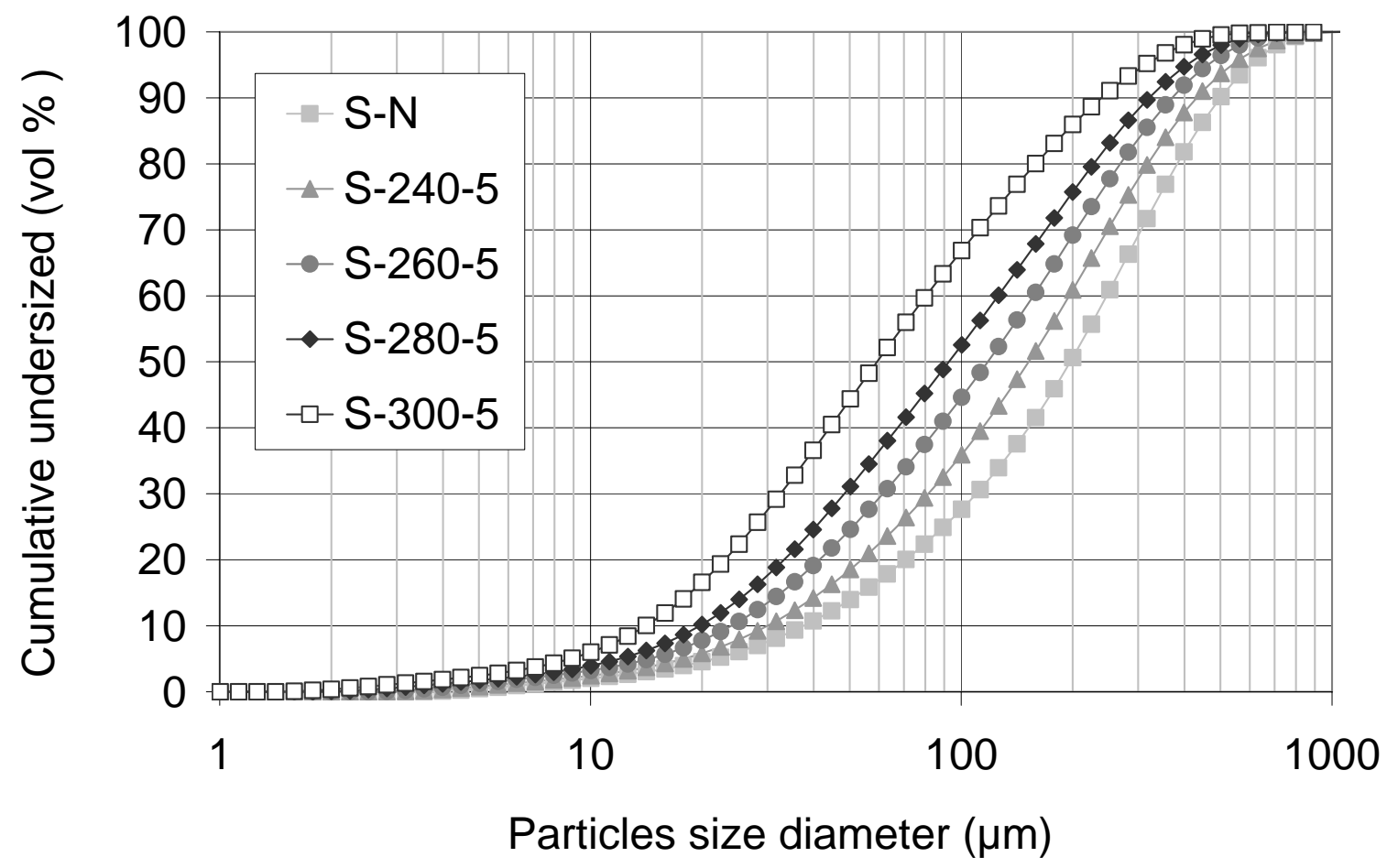

Figure 4: Particle size distribution of fine powder of spruce wood (natural and torrefied at different temperatures).

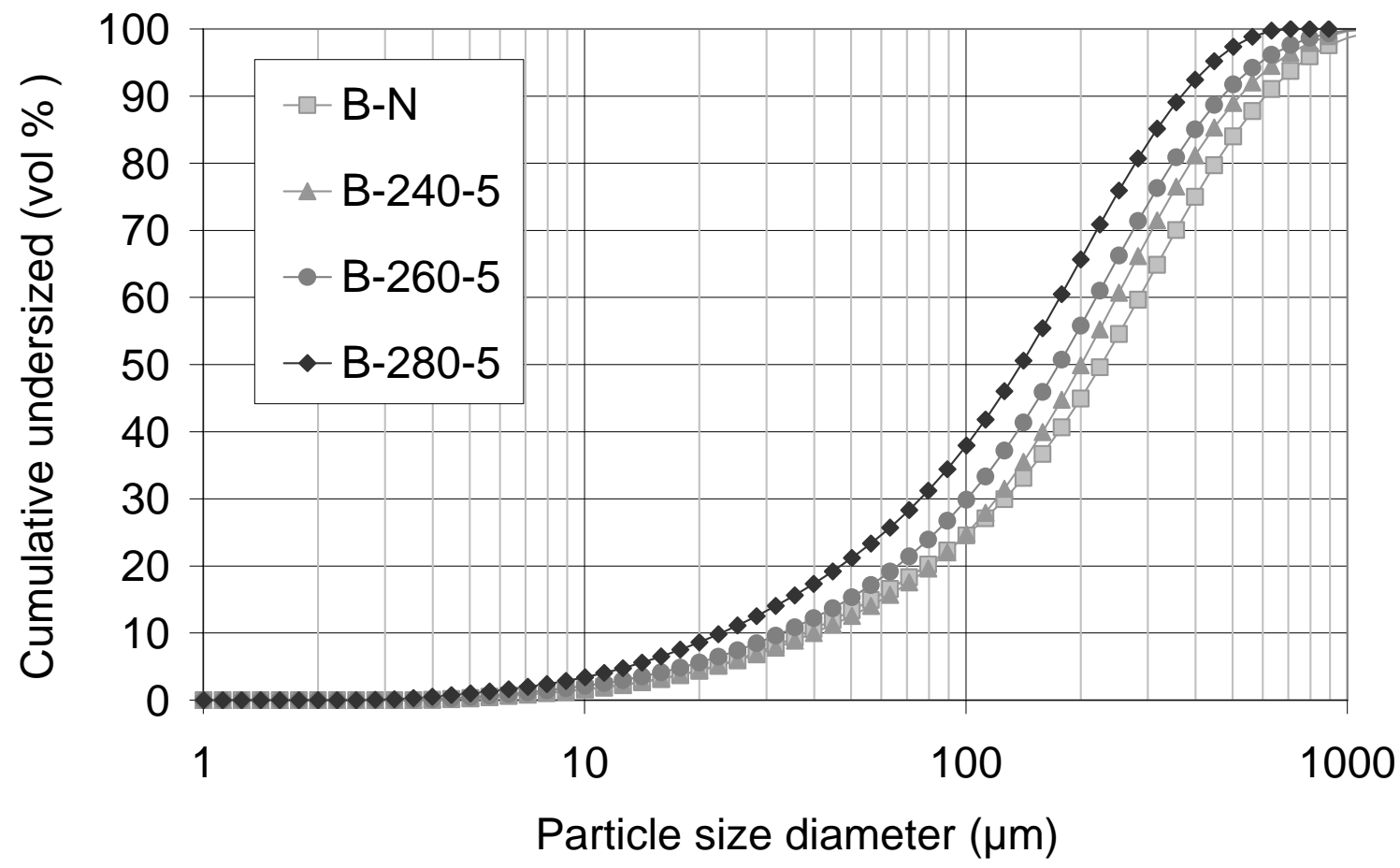

Figure 5: Particle size distribution of fine powder of beech wood (natural and torrefied at different temperatures). 


\section{Discussion}

These results may be explained by the physical and chemical phenomena involved in torrefaction. A mechanism in two steps is proposed. The first step is due to the transformations occurring during heat treatments at low temperature (S-160-5 and B-180-5). During this first step, no AWL happens. The second step is due to the progress of heat treatment and thermal decomposition of wood constituents, in relationship with an increase of AWL.

\section{IV.1. Effect of temperature on wood grinding: first step}

Phenomena involved during this first step, may mainly be attributed to dehydration and lignin physical transformations.

Dehydration induces a shrinking of the ligno-cellulosic material. This may create some stress in wood fibres that can favour cracks or defect creations. The structure shrinking induces porosity and density changes. During low temperature treatments, density varies in a different way depending on wood species. A previous study has shown that heat treatments at low temperature increase beech density, whereas they decrease maritime pine density [33] Repellin V. Optimisation des paramètres durée et température d'un traitement thermique du bois. Modification des propriétés d'usage du bois en relation avec les modifications physicochimiques et ultrastructurales occasionnées par le traitement thermique. PhD Thesis Report, Ecole des Mines de saint Etienne, Saint-Etienne, France; 2006. p. 129.[33]. Moreover, resin evaporation could occur for softwood and enhance the decrease of density [33].

During this first step, lignin passes through its glass transition and softens. If cellulose is in a stressed state, tensions may be released by cracks or fiber/network defect creations. Moreover, after cooling lignin is in a tightened state. Tightening wood structure by low temperature heat treatments was thoroughly studied by Obataya and Tomita [34]. In this stiff state, treated wood has a decreased plastic and viscoelastic behaviour by comparison to natural wood. In this state, a crack can propagate easily.

Thus, crack creations, density decrease and material stiffening favour energy decrease and finer particles sizes. It is visible for spruce (S-160-5) on the WFI2 (Figure 2), on the grinding energy (Figure 3) and on the fine powder particles sizes. Concerning B-180-5, the trends are the same on WFI2 (Figure 2) and grinding energy, the grinding energy decrease being lower for beech than for spruce (Figure 3). However, the particle size of fine powder is not decreased, and even slightly increased (Table 4). A slight increase of density is observed for beech wood treated at low temperature [33]. This density increase probably counterbalances the creation of cracks and material stiffening.

\section{IV.2. Effect of temperature on wood grinding: second stage}

The second stage begins with thermal decomposition of wood. Thermal decomposition of wood results in a progressive and general embrittlement and degradation of wood cell walls. Consequently, the WFI2 increases (Figure 2), grinding energy (Figure 3) and fine powder particle sizes decrease, both for spruce and for beech ([Table 3] and [Table 4]).

The WFI2 increases significantly between $200{ }^{\circ} \mathrm{C}$ and $220^{\circ} \mathrm{C}$ for beech and between $240{ }^{\circ} \mathrm{C}$ and $260^{\circ} \mathrm{C}$ for spruce (Figure 2). For fine grinding, significant decrease of particle size occurs at $260{ }^{\circ} \mathrm{C}$ for spruce and $240{ }^{\circ} \mathrm{C}$ for beech ([Table 3] and [Table 4]). Effects of torrefaction on grinding energy, particle size distribution and WFI2 happen at lower temperature for beech than for spruce. As a result, grinding energy of beech becomes inferior to grinding energy of spruce at $220^{\circ} \mathrm{C}$ (Figure 3 ).

Chemical composition of spruce and beech could explain these differences. Wood thermal degradation begins by hemicelluloses degradation. Among hemicelluloses, xylans thermal decomposition occurs at lower temperature than other hemicelluloses [18], [21], [22] and [35]. Beech contains more xylanes (27.5\%) than spruce (8.6\%) [36]. Consequently, thermal degradation occurs at lower temperatures for beech than for spruce. The temperature required to reach a given value of the grinding energy depends on the wood species. For optimising torrefaction and grinding processes, a particular care must be paid to the type of biomass employed. 


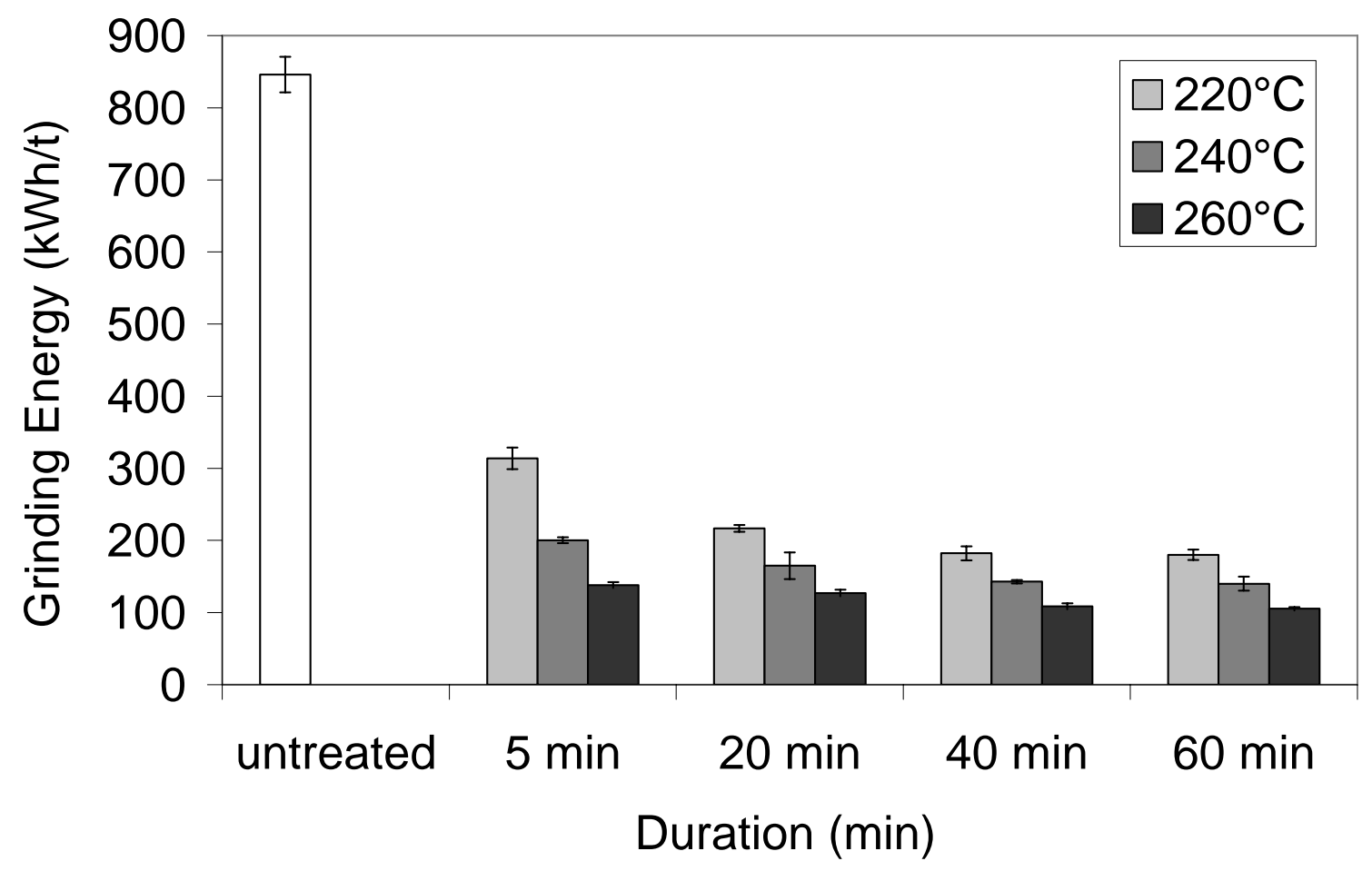

Figure 6: Grinding energy of beech as a function of torrefaction duration, obtained with a Retsch ZM1 ultra centrifugal mill equipped with a $500 \mu \mathrm{m}$ grid.

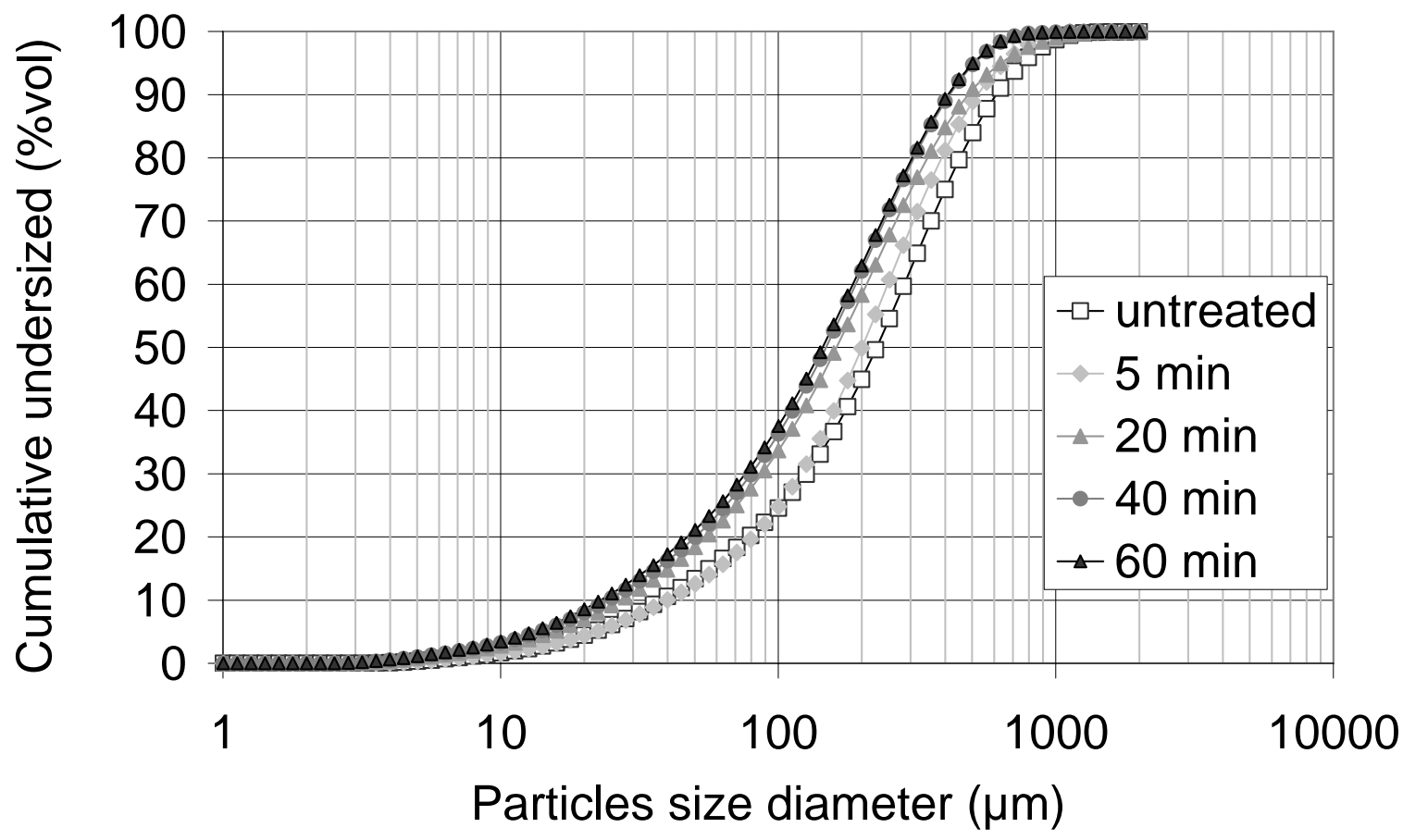

Figure 7: Particle size distribution of fine powder of beech wood (natural and torrefied at $240{ }^{\circ} \mathrm{C}$ for different durations).

IV.3. Fine grinding energy and particle sizes vs. AWL

On one hand, the two species do not begin their thermal decomposition at the same temperature. On the other hand, thermal decomposition is characterised by the AWL of wood. 
To observe the influence of thermal decomposition on wood grindability, grinding energies and powders average particle sizes were plotted against anhydrous weight loss.

On Figure 8, it is visible that during the first step (low temperature torrefaction - no anhydrous weight loss) wood grinding energy of the two species decreases by around $300 \mathrm{kWh} / \mathrm{t}$. This first step has thus a strong influence on wood grindability. When the AWL increases, spruce and beech grinding energy values are very close and vary similarly in function of the AWL. Grinding energy decreases rapidly when the AWL increases from $0 \%$ to $8 \%$. Over $8 \%$, grinding energy decreases at a slow rate. Above $8 \%$ of AWL, any decrease of grinding energy requires high loss of material, and thus high loss of the energy initially contained in wood. Regardless a total energy balance of torrefaction and fine grinding, $8 \%$ of AWL may be considered as an optimum value to reduce wood grinding energy while maintaining a good energy yield.

Table 4: Properties of particle size distribution of beech wood powder, obtained with a Retsch ZM1 ultra centrifugal mill equipped with a $500 \mu \mathrm{m}$ grid (Average of 4 samples, standard deviation in brackets.).

\begin{tabular}{|l|lll|}
\hline Name & Mode (jm) & D $_{[4,3]}(\boldsymbol{\mu m})$ & $\mathbf{D}_{\mathbf{5 0}}(\boldsymbol{\mu m})$ \\
\hline B-N & $304(6)$ & $284(13)$ & $227(6)$ \\
B-180-5 & $306(5)$ & $306(17)$ & $239(6)$ \\
B-200-5 & $298(15)$ & $294(26)$ & $237(13)$ \\
B-220-5 & $270(6)$ & $280(29)$ & $223(11)$ \\
B-240-5 & $250(2)$ & $248(4)$ & $200(4)$ \\
B-260-5 & $232(6)$ & $221(6)$ & $175(5)$ \\
B-280-5 & $201(7)$ & $171(2)$ & $140(1)$ \\
\hline B-220-20 & $247(4)$ & $242(9)$ & $192(6)$ \\
B-240-20 & $224(4)$ & $221(5)$ & $163(4)$ \\
B-260-20 & $203(2)$ & $184(6)$ & $140(3)$ \\
\hline B-220-40 & $239(3)$ & $230(12)$ & $178(6)$ \\
B-240-40 & $218(5)$ & $190(6)$ & $149(3)$ \\
B-260-40 & $204(2)$ & $185(3)$ & $141(1)$ \\
\hline B-220-60 & $235(6)$ & $227(11)$ & $175(7)$ \\
B-240-60 & $218(5)$ & $186(10)$ & $145(4)$ \\
B-260-60 & $202(5)$ & $178(10)$ & $142(5)$ \\
\hline
\end{tabular}

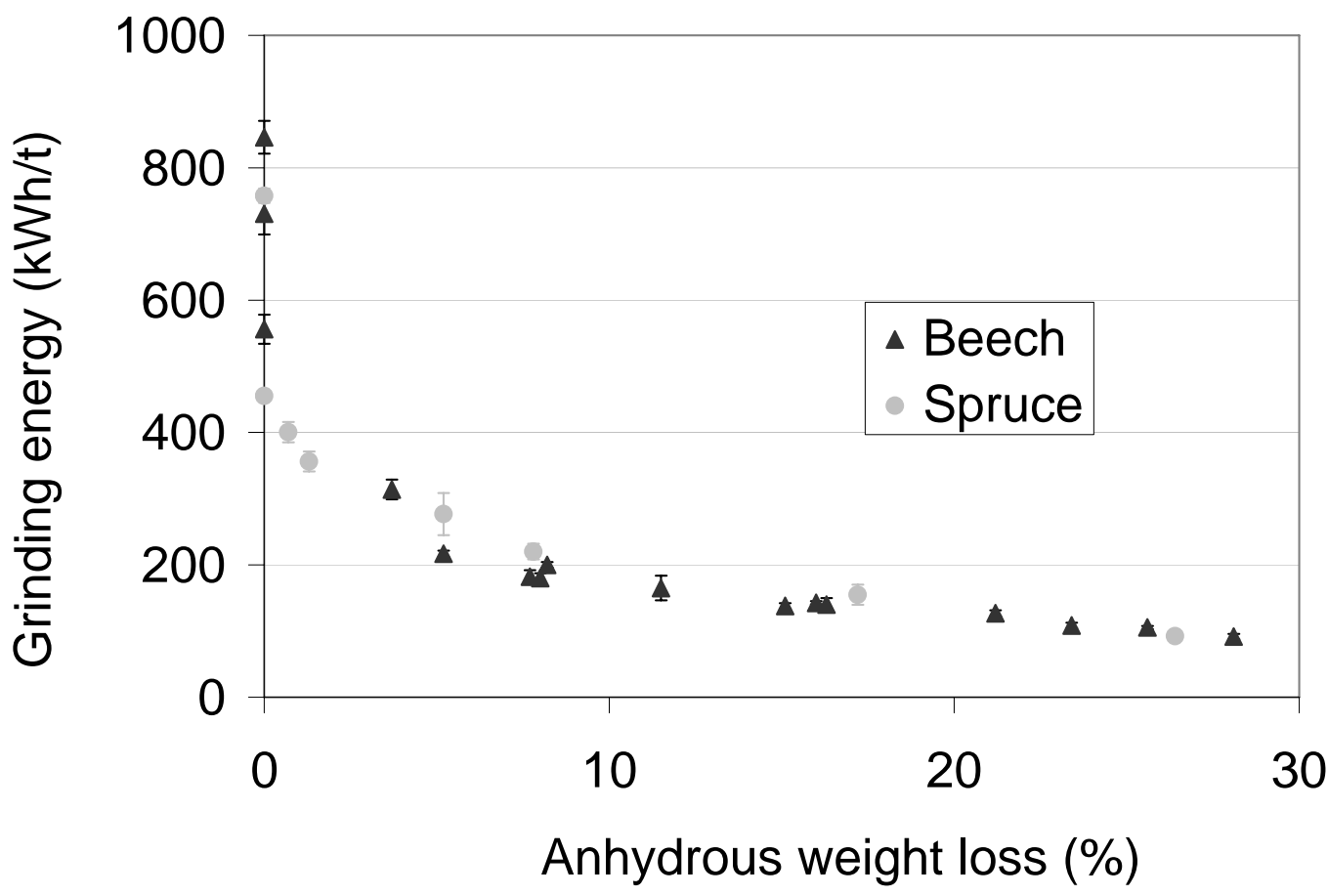

Figure 8: Grinding energy as a function of anhydrous weight loss for beech and spruce

The average particle size decreases progressively and almost linearly as the AWL increases until 30\%. The rate of decrease is globally similar for spruce and for beech. Average particle 
sizes are higher for beech than for spruce whatever the AWL. The difference between the average particle size of beech and spruce is almost constant (Figure 9).

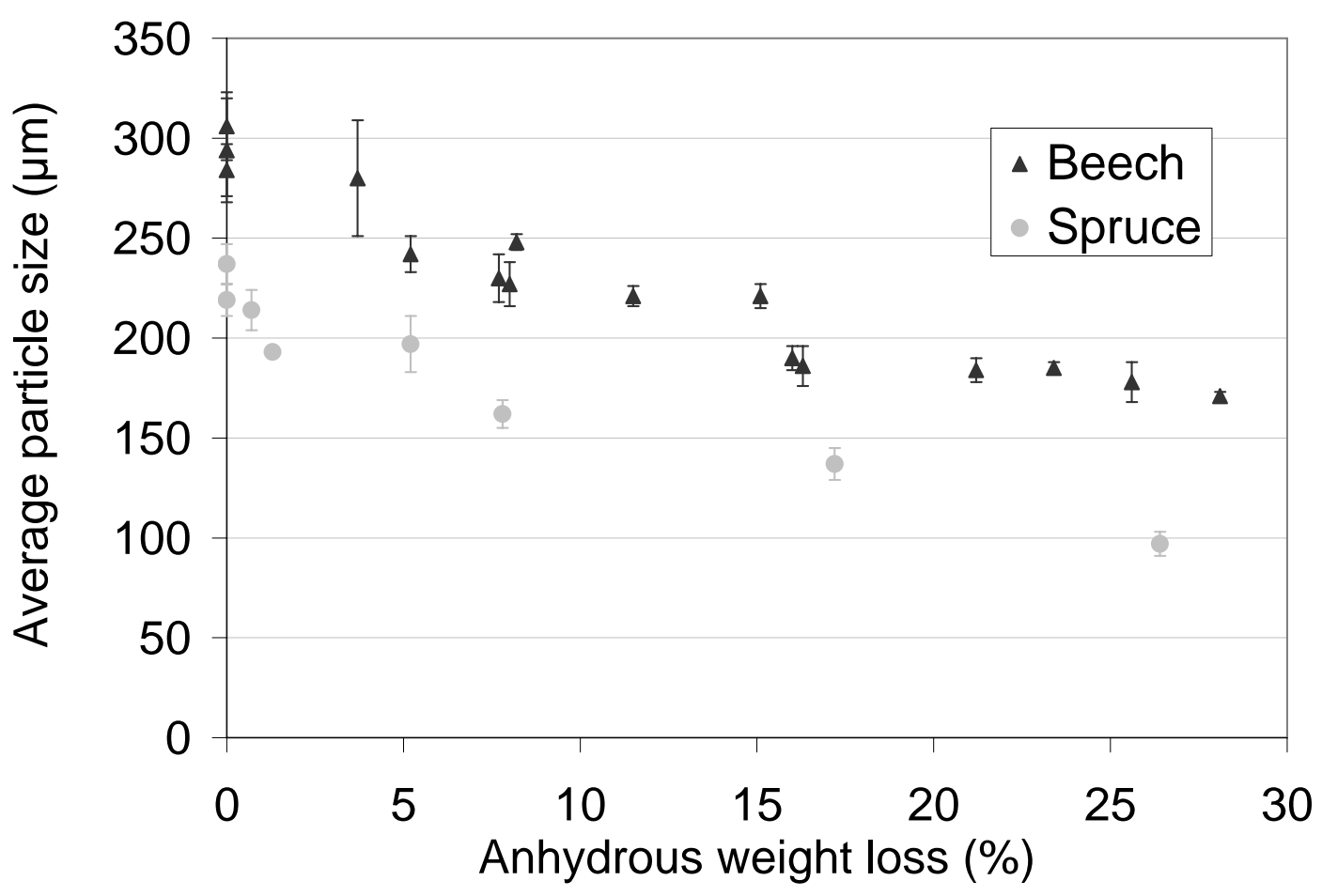

Figure 9: Average particle size diameter as a function of anhydrous weight loss involved by torrefaction.

IV.4. Grindability criterion at $200 \mu \mathrm{m}$

To evaluate the real impact of torrefaction on wood grindability, both grinding energy and particle size distribution must be taken into account. In this study, it is intended to compare grindability of natural wood and wood torrefied at different temperatures. For this purpose, we propose a grindability criterion inspired from Sokolowski's works [37]. This criterion $(G)$ is given by the ratio between grinding energy $(E)$ and the volumetric fraction of particles inferior to $200 \mu \mathrm{m}\left(\mathrm{X}_{<200 \mu \mathrm{m}}\right) . G$ is calculated from experimental data according to the following equation:

$$
\mathrm{G}=\frac{\mathrm{E}}{\mathrm{X}_{<200 \mu m}}
$$

Some authors defined and used $G$ to compare grinding energy required to reduce wheat to flour (particles inferior to $200 \mu \mathrm{m}$ ). $G$ was found 'easy to evaluate and very discriminatory' [38] and [39]. $\mathrm{G}$ is determined for given grinding conditions: type of mill, size of the grinding grid holes. It gives comparable results only if the particle size distribution of the feeding materials is well defined and identical for each material. It is useful to compare different materials. Figure 10 presents the results of $G$ in function of the AWL. Variations are very similar to those of grinding energy. As the particle size distribution is taken into account, differences between the two species are enhanced. At low AWL, G is superior for beech than for spruce. At AWL close to $5 \%, G$ of beech is reduced 4.5 times whereas it is reduced only 3.3 times for spruce. When the AWL increases over $5 \%, G$ has the same value for beech and for spruce. For AWL around $8 \%, G$ is 4.7 times lower than $G$ of natural wood, both for spruce (S260-5) and beech (B-240-5). $G$ provides an evaluation of the amount of energy that can be saved owing to torrefaction. For AWL close to $28 \%, G$ is drastically reduced by $13-14$ times in comparison with natural wood (S-300-5, B-280-5). $G$ is a sensitive parameter to compare fine grinding energy of natural and torrefied wood. 


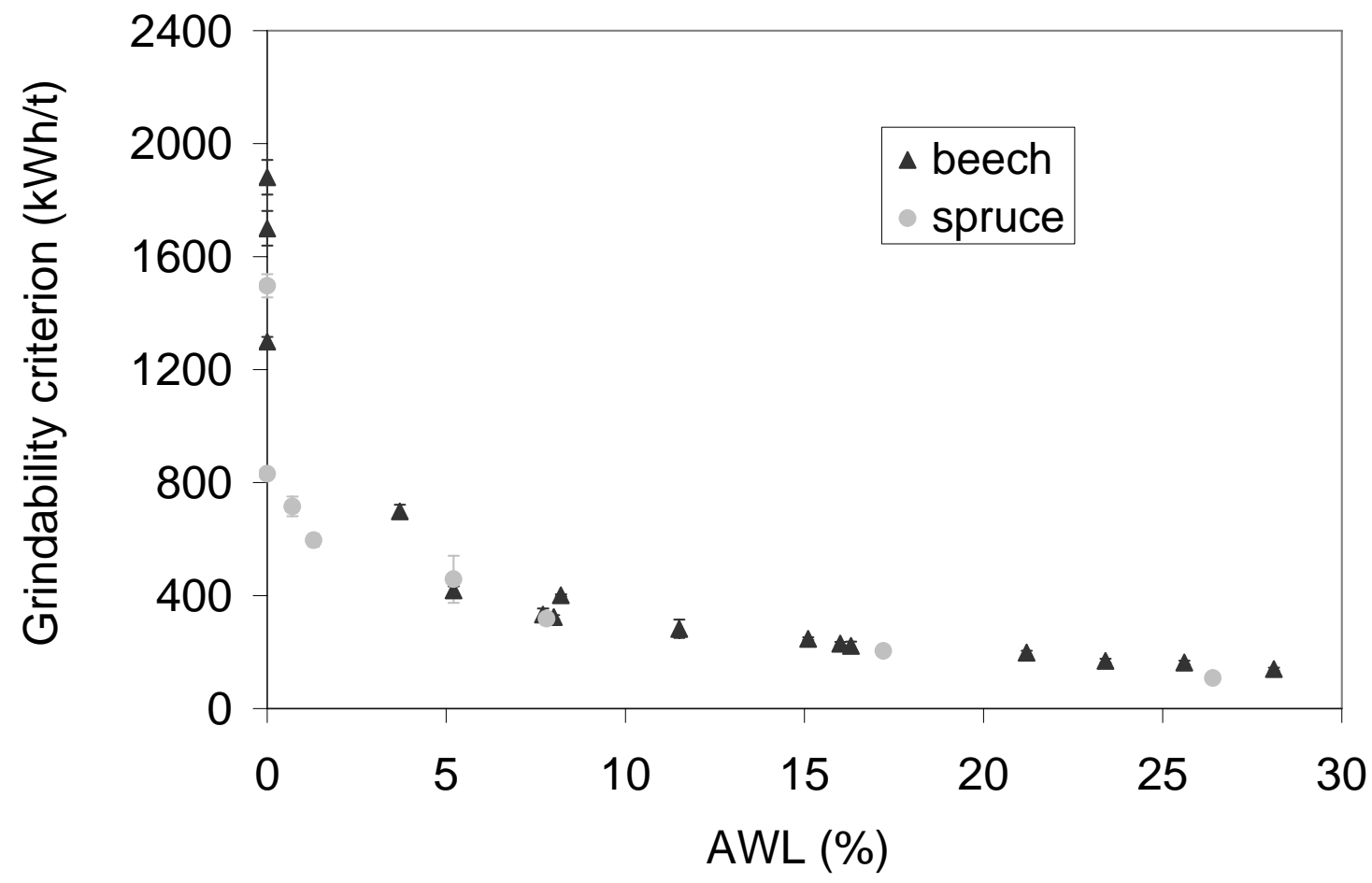

Figure 10: Grinding criterion as a function of anhydrous weight loss for beech and spruce.

\section{Conclusions}

An experimental protocol was established to measure fine grinding energy of wood. Wood grinding energy is high: about one sixth of natural wood LHV. Torrefaction decreases both grinding energy and particle size distribution. A two stage mechanism was observed. The first stage involves density variations, dehydration and lignin glass transition. It happens at low temperature. It decreases grinding energy, but has low impact on particle size distribution. The second stage matches to thermal degradation of wood. It is characterised by the anhydrous weight loss of wood. For AWL inferior to around 8\%, grinding energy decreases fast. Over 8\%, grinding energy decreases at a slow rate. Particle size distribution decreases linearly as the anhydrous weight loss increases. A criterion to compare grindability of different material (natural wood and wood torrefied at different temperatures and durations) is proposed. It takes into account both grinding energy and particle size. It matches to the energy required for grinding particles to sizes inferior to $200 \mu \mathrm{m}$, for given grinding conditions. For AWL around 8\%, $G$ is 4.7 times lower than $G$ of natural wood. Both for spruce and beech, the grinding criterion is decreased of $93 \%$ when the AWL is around $28 \%$.

\section{References}

[1] A. Demirbaş, Combustion characteristics of different biomass fuels, Progress in Energy and Combustion Science 30 (2004), pp. 219-230.

[2] A. Demirbaş, Importance of biodiesel as transportation fuel, Energy Policy 35 (2007), pp. 4661-4670.

[3] A. Demirbaş, Biomass resource facilities and biomass conversion processing for fuels and chemicals, Energy Conversion and Management 42 (2001), pp. 1357-1378.

[4] G. Claudet, E. Marty and J.M. Seiler, Produire du carburant par la transformation thermochimique de la biomasse, Clefs CEA 50 (2004), pp. 42-46.

[5] A. Demirbaş, Progress and recent trends in biofuels, Progress in energy and combustion science 33 (2007), pp. 1-18.

[6] H. Schulz, Short history and present trends of Fischer-Tropsch synthesis, Applied Catalysis A General 186 (1999), pp. 3-12. 
[7] M.J. Prins, K.J. Ptasinski and F.J.J.G. Janssen, Exergetic optimisation of a production process of Fischer-Tropsch fuels from biomass, Fuel Processing Technology 86 (2004), pp. 375-389.

[8] L. Wei, S. Xu, L. Zhang, H. Zhang, C. Liu and H. Zhu et al., Characteristics of fast pyrolysis of biomass in a free fall reactor, Fuel Processing Technology 87 (2006), pp. 863-871.

[9] G.M. Simmons and M. Gentry, Particle size limitations due to heat transfer in determining pyrolysis kinetics of biomass, Journal of Analytical and Applied Pyrolysis 10 (1986), pp. 117-127.

[10] G. Schubert and S. Bernotat, Comminution of non brittle materials, International Journal of Mineral Processing 74 (2004), pp. 19-30.

[11] M. Himmel, M. Tucker, J. Baker, C. Rivard, K. Oh and K. Grohmann, Comminution of biomass: hammer and knife mills, Biotechnology and Bioengineering Symposium 15 (1985), pp. 39-58.

[12] M.T. Holtzapple, A.E. Humphrey and J.D. Taylor, Energy requirements for the size reduction of poplar and aspen wood, Biotechnology and Bioengineering 33 (1989), pp. 207-210.

[13] L.S. Esteban and J.E. Carrasco, Evaluation of different strategies for pulverisation of forest biomasses, Powder Technology 166 (2006), pp. 139-151.

[14] J. Reina, E. Velo and L. Puigjaner, Predicting the minimum fluidisation velocity of polydisperse mixtures of scrap-wood particles, Powder Technology 111 (2000), pp. $245-251$.

[15] D. Geldart, Types of gas fluidization, Powder Technology 7 (1973), pp. 285-292.

[16] S. Paulrud, J.E. Mattson and C. Nilsson, Particle and handling characteristics of wood fuel powder: effect of different mills, Fuel Processing Technology 76 (2002), pp. 23-39.

[17] N. Kobayashi, P. Guilin, J. Kobayashi, S. Hatano, Y. Itaya and S. Mori, A new pulverized biomass utilization technology, Powder Technology 180 (2008), pp. 272-283.

[18] V. Repellin, A. Govin, M. Rolland and R. Guyonnet, Modelling anhydrous weight loss of wood chips during torrefaction in a pilot kiln, Biomass and Bioenergy (2010), 34(5), pp. 602-609, 10.1016/j.biombioe.2010.01.002., $\quad$ http://hal.archives-ouvertes.fr/hal$00477323 / \mathrm{fr} /$.

[19] D. Fengel and G. Wegener, Wood chemistry, ultrastructure, reactions, Walter De Gruyter, Berlin (1983).

[20] Browne FL. Theories of the combustion of wood and its control. Report no. 2136. USDA Forest service; 1958.

[21] W.F. Degroot, W.P. Pan, D. Rahman and G.N. Richards, First chemical events in pyrolysis of wood, Journal of Analytical and Applied Pyrolysis 13 (1988), pp. 221-231.

[22] J.J. Weiland, R. Guyonnet and R. Gibert, Analysis of controlled wood burning by combination of thermogravimetric analysis, differential scanning calorimetry and Fourier transform infrared spectroscopy, Journal of Thermal Analysis and Calorimetry 51 (1998), pp. 265-274.

[23] T. Elder, Pyrolysis of wood. In: D.N.S. Hon and N. Shiraishi, Editors, Wood and cellulosic chemistry, Marcel Dekker Inc, New York and Basel (1991), pp. 665-699.

[24] Bergman PCA, Kiel JHA. Torrefaction for biomass upgrading. In : 14th European Biomass Conference and Exhibition; 2005.

[25] A.O. Rapp, C. Brischke and C.R. Welzbacher, Interrelationship between the severity of heat treatments and sieve fractions after impact ball milling: a mechanical test for quality control of thermally modified wood, Holzforschung 60 (2006), pp. 64-70.

[26] P. Niemz and P. Bekhta, Effect of high temperature on the change in color, dimensional stability and mechanical properties of spruce wood, Holzforschung 57 (2003), pp. 539546.

[27] V. Repellin and R. Guyonnet, Evaluation of heat treated beech by non destructive testing. In: J. Van Acker and C. Hill, Editors, Proceedings of the first European conference on wood modification, Ghent University, Ghent (2003), pp. 73-82. http://hal.archives-ouvertes.fr/hal-00123723/fr/ 
[28] J. Bourgois and R. Guyonnet, Characterisation and analysis of torrefied wood, Wood Science and Technology 22 (1988), pp. 143-155.

[29] J. Bourgois, M.C. Bartholin and R. Guyonnet, Thermal treatment of wood: analysis of the obtain product, Wood Science and Technology 23 (1989), pp. 303-310.

[30] V. Repellin and R. Guyonnet, Evaluation of heat-treated wood swelling by differential scanning calorimetry in relation to chemical composition, Holzforschung 59 (2005), pp. 28-34, http://hal.archives-ouvertes.fr/hal-00123858/fr/

[31] Bergman PCA, Boersma AR, Zwart RWR, Kiel JHA. Torrefaction for biomass co-firing in existing coal-fired power stations. Report no. ECN-C-05-013. Biomass Coal and Environmental Research, ECN, Petten, Netherland; 2005.

[32] Bergman PCA. Combined torrefaction and pelletisation: the TOP process. Repport no. ECN-C-05-073. Biomass Coal and Environmental Research, ECN, Petten, Netherland; 2005

[33] Repellin V. Optimisation des paramètres durée et température d'un traitement thermique du bois. Modification des propriétés d'usage du bois en relation avec les modifications physico-chimiques et ultrastructurales occasionnées par le traitement thermique. PhD Thesis Report, Ecole des Mines de saint Etienne, Saint-Etienne, France; 2006. p. 129, http://tel.archives-ouvertes.fr/tel-00012090/fr/

[34] E. Obataya and B. Tomita, Hygroscopicity of heat treated wood II - reversible reductions in the hygroscopicity of wood due to heating, Mokuzai Gakkaishi 48 (2002), pp. 288-295.

[35] K. Shimizu, F. Teratani and K. Miyazaki, Effect of thermal treatment on wood hemicelluloses IV: mechanism in early stage of xylan pyrolysis, Journal of Japanese Wood Research Society 17 (1971), pp. 154-159.

[36] E. Sjöström, Wood chemistry: fundamentals and applications (2nd ed.), Academic Press, San Diego (1993) p. 249.

[37] M. Sokolowski, Energy consumed in comminution - a new idea of a general law of comminution - new test stands and testing results, Récents progress en genie des procédés 10 (1996), pp. 221-226.

[38] R. Pujol, C. Létang, I. Lempereur, M. Chaurand, F. Mabille and J. Abecassis, Description of a micromill with instrumentation for measuring grinding characteristics of wheat grain, Cereal Chemistry 77 (2000), pp. 421-427.

[39] V. Greffeuille, J. Abecassis, N. Barouh, P. Villeneuve, F. Mabille and C. Bar L'Helgouac'h et al., Analysis of the milling reduction of bread wheat farina: physical and biochemical characterisation, Journal of Cereal Science 45 (2007), pp. 97-105. 